Acta Agroph., 2019, 26(1), 47-56

doi: $10.31545 /$ aagr/108561

\title{
SUMMER- AND AUTUMN-FRUITING RASPBERRY QUALITY AS INFLUENCED BY THE HARVEST DATE
}

\author{
Bogumit Markuszewski@, Karol Wysocki, Jan Kopytowski@ \\ Department of Horticulture, Faculty of Environmental Managament and Agriculture \\ Universuty of Warmia Mazury in Olsztyn, ul. Prawocheńskiego 21, 10-957 Olsztyn, Poland \\ e-mail: bogumil.markuszewski@uwm.edu.pl
}

\begin{abstract}
During a three-year study conducted at the Experimental Garden of the University of Warmia and Mazury in Olsztyn, the yield and quality of raspberry fruit of the summer-fruiting cultivars 'Benefis', 'Laszka' and the autumn-fruiting cultivars 'Polesie', 'Polka' and 'Popiel' were evaluated. The raspberry harvest was carried out on three carefully selected dates, i.e. for summer-fruiting cultivars: in the first, second and third decades of July and for autumn-fruiting cultivars in the second decade of August and the first and third decades of September. The highest yields were obtained from the cultivars 'Polesie' and 'Polka'. The fruit of the tested cultivars collected during the third term had significantly lower masses. The highest contents of dry matter in fruit were recorded for 'Polka' and of organic acids for 'Popiel' and 'Benefis'. The fruit harvested in the second and the third term had a higher content of dry matter.

Keyw ords: chemical composition of fruit, floricane raspberry, primocane raspberry
\end{abstract}

\section{INTRODUCTION}

Raspberry (Rubus idaeus L.) is one of the most important crops among fruitbearing species cultivated in Poland. Raspberry fruit are characterized by valuable nutritional, dietary and health benefits (Krauze-Baranowska and Majdan 2009). They constitute a valuable source of bioactive substances such as phenols, carotenoids and anthocyanins displaying antibacterial and antiproliferative activities (Liu et al. 2002). The concentrations of these compounds depend, among other factors, on the stage of fruit maturity during harvest (Miret and Munne-Bosch 2016). Raspberry fruit also contain numerous vitamins, minerals and organic acids (Mazur et al. 2014).

Raspberry cultivars cultivated in Poland belong to one of two groups. One group are plants that bear fruit in the summer on the previous year's shoots, which include, among others, cultivars such as 'Benefis' and 'Laszka', 'Tulameen', 'Citria' and 'Glen Ample'. The second group consists of cultivars bearing fruit in late summer 
and autumn on the upper parts of annual shoots and at the usual time of fruiting the following year, on the lower parts of the same shoots. This group includes cultivars such as 'Polesie' and 'Polana', 'Pokusa', 'Polka' and 'Popiel' (Król et al. 2008). Trends in planting on a national scale have changed in favour of autumn-fruiting cultivars, characterized by a high yield potential (Danek and Król 2005). It was found that these cultivars have a higher demand for nutrients than summer-fruiting cultivars (Krawiec and Rybczyński 2010). In addition to fertilization (Buskiene and Uselis 2008), there were drought periods during the growing season (LaszlovszkyZmarlicka and Smolarz 2003). Raspberries belong to a group of orchard fruit plants, which have large water needs. Providing irrigation during flowering and fruiting promotes high yields and higher quality of raspberry fruit (Treder et al. 1993; Koszański and Rumasz-Rudnicka 2008, Krawiec and Rybczyński 2010).

Having multiple fruit harvests during ripening provides an opportunity to harvest the highest quality fruits. The fruit collected at the stage of consumer maturity are characterized by optimal colour, aroma and size (Krawiec and Rybczyński 2010). Multiple harvests are only possible in a limited area, due to the high demand for labour and related costs. Therefore, one of the basic conditions for increasing the growing area and profitability of raspberry production is harvesting with a combine (Kowalczuk et al. 2008).

The aim of the study wtas to assess the yield and quality of raspberry fruit depending on the cultivar and date of harvest in north-eastern Poland.

\section{MATERIAL AND METHODS}

The experiment was carried out in 2010-2012 at the Experimental and Educational Garden of the University of Warmia and Mazury in Olsztyn. The research material were cultivars of raspberries bearing fruit in the summer: 'Laszka' and 'Benefis' and those fruiting in the autumn: 'Polesie', 'Polka' and 'Popiel'. Raspberry bushes were planted in 2008 in $60 \mathrm{~m}^{2}$ plots with a spacing of $3 \times 0.25 \mathrm{~m}$, without supports. The experiment was carried out in three replications. The assessment of yield (the sum of fruit obtained from the whole plot area calculated per $1 \mathrm{ha}$ ), fruit weight (based on a representative sample of 60 fruit) and chemical analyses of fruit (per $1 \mathrm{~kg}$ sample) was made in three replications on three dates, depending on the cultivar: summer-fruiting raspberries in the first, second and third decades of July, and autumn-fruiting raspberries in the second decade of August and the first and third decades of September. Samples of fruit undamaged and devoid of fungal infections were subjected to laboratory analysis, which were made according to the procedures described in Polish Standards, the analyses consisted of: dry matter (PN-90/A-75101/03), organic acids (PN-90/A-75101/04), total sugars (PN90/A-75101/07) and vitamin C (with Tillman's method modified by Pijanowski). 
The results of the chemical analysis of raspberry fruit produced by summer-fruiting cultivars for the first year of research have been lost, which is why they are missing from the study. The obtained results were subjected to a two-factor analysis of ANOVA variance, determining the cultivar as the first factor and the date of harvest as the second factor, using Statistica 12.0 software. The significance of differences was assessed using the HSD-Tukey test, with a significance level of $\alpha=0.05$.

\section{RESULTS}

The analysis of the influence of the cultivar and the date of fruit harvest on the yield and quality of raspberry fruit showed significant differences between the average values of the studied properties. The impact of the studied factors was substantially modified by the meteorological conditions of individual years (Fig. 1).

The highest fruit yield was obtained from the 'Polesie' cultivar (Tab. 1). The 'Polka' was also characterized by high yields compared with the remaining cultivars, which yielded 2-3-fold lower levels, among which the 'Popiel' cultivar showed the lowest yields. The impact of fruit harvesting time on the raspberry yield in particular years of research was significant as each year had a tendency towards higher yields for the second harvest. Lower yields on the first and third harvesting dates, especially in the first and third year of research in the case of cultivars that yielded in the summer, were associated with a low average sum of precipitation (Fig. 1).

An analysis of the impact of the studied factors on the mass of the fruit according to the average values from the years of research showed significant differences only in the case of the harvesting date, where a higher fruit weight was recorded for the first and second harvest (Tab. 2).

An analysis of the average content of dry matter in fruit during the three years of research showed a significantly higher level of dry matter in the 'Polka' cultivar compared with the other cultivars (Tab. 3). The content of dry matter in raspberry fruit was also significantly influenced by the date of harvesting. Higher levels of dry matter were recorded in fruit from the second and third harvest. In particular years of research, a similar relationship was maintained with the content of dry matter in fruit. Also, in the second year, the highest content of dry matter in fruit, in addition to the 'Polka' cultivar, was shown by the 'Laszka' cultivar.

The average content of vitamin $\mathrm{C}$ (L-ascorbic acid) in the fruit of the raspberry cultivars studied was $23.7-26.7 \mathrm{mg} \cdot 100 \mathrm{~g}^{-1}$ of fresh fruit (Tab. 4). On the basis of the average of the years studied, there appeared to be no significant effect of cultivar and harvest date on the content of the vitamin in the fruit. Depending on the season, the significantly highest content of L-ascorbic acid in the fruit was shown by 'Polesie' and 'Laszka' (in the second year), 'Polka' (in the first year) and 'Laszka' (in the third year). It was found that the harvest time of the fruit had 
a significant influence over the content of the tested component in the first and second year of the study, where a higher content of vitamin $\mathrm{C}$ was recorded for the first, second and third fruit harvests.
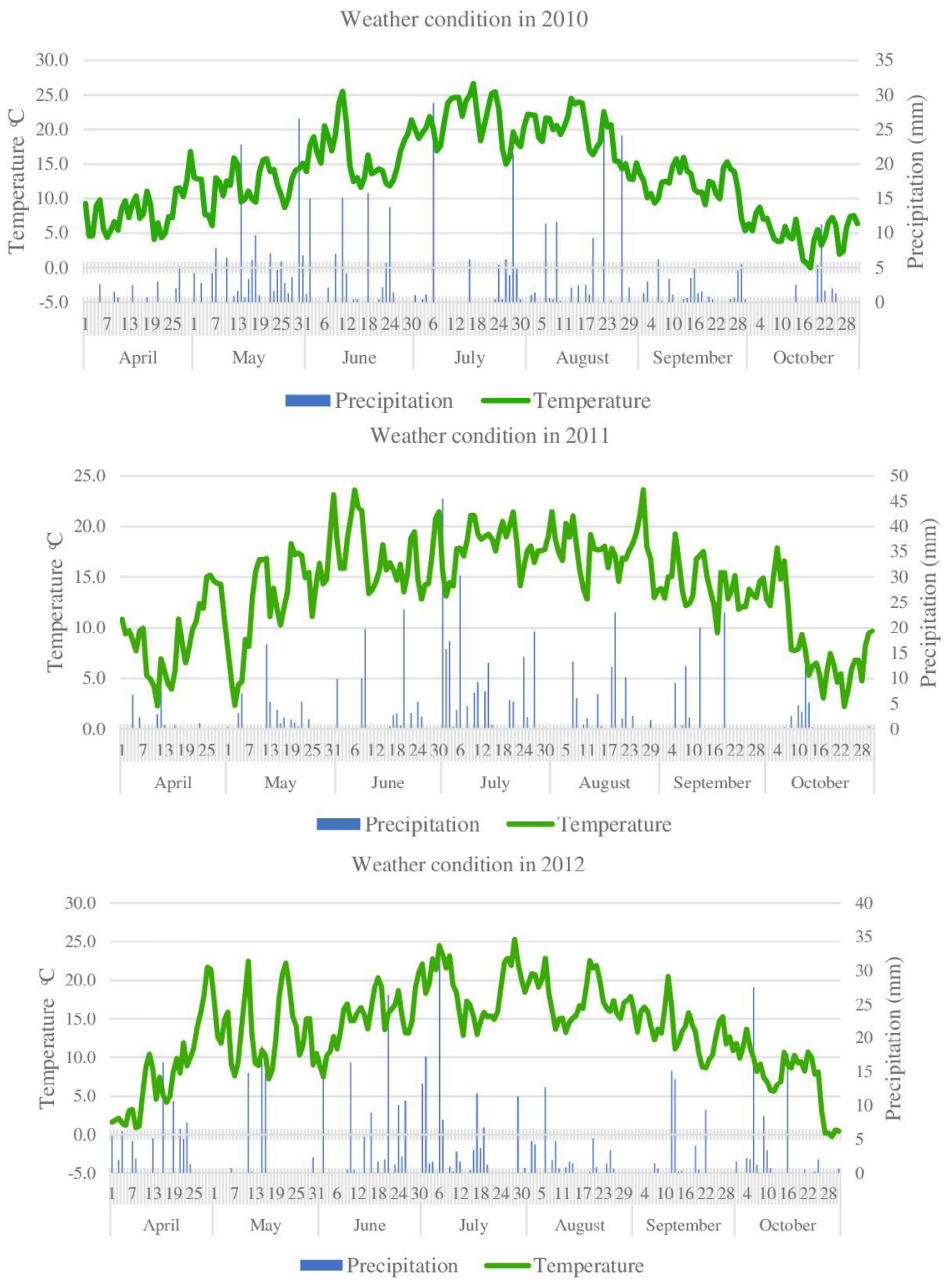

Fig. 1. Meteorological conditions during raspberry fruit vegetation periods in the 2010-2012 season

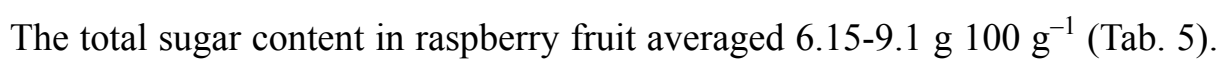
On the basis of the average of all the years of research, there was no significant effect found for the cultivar or harvest date on the sugar content of the fruit. In analysing individual years of research, significant differences between cultivars were found in the first and third year, in which the 'Polka' cultivar had a higher sugar content. The impact of fruit harvest time differed significantly for all years of research, where a higher sugar content was recorded in the second and third harvest. 


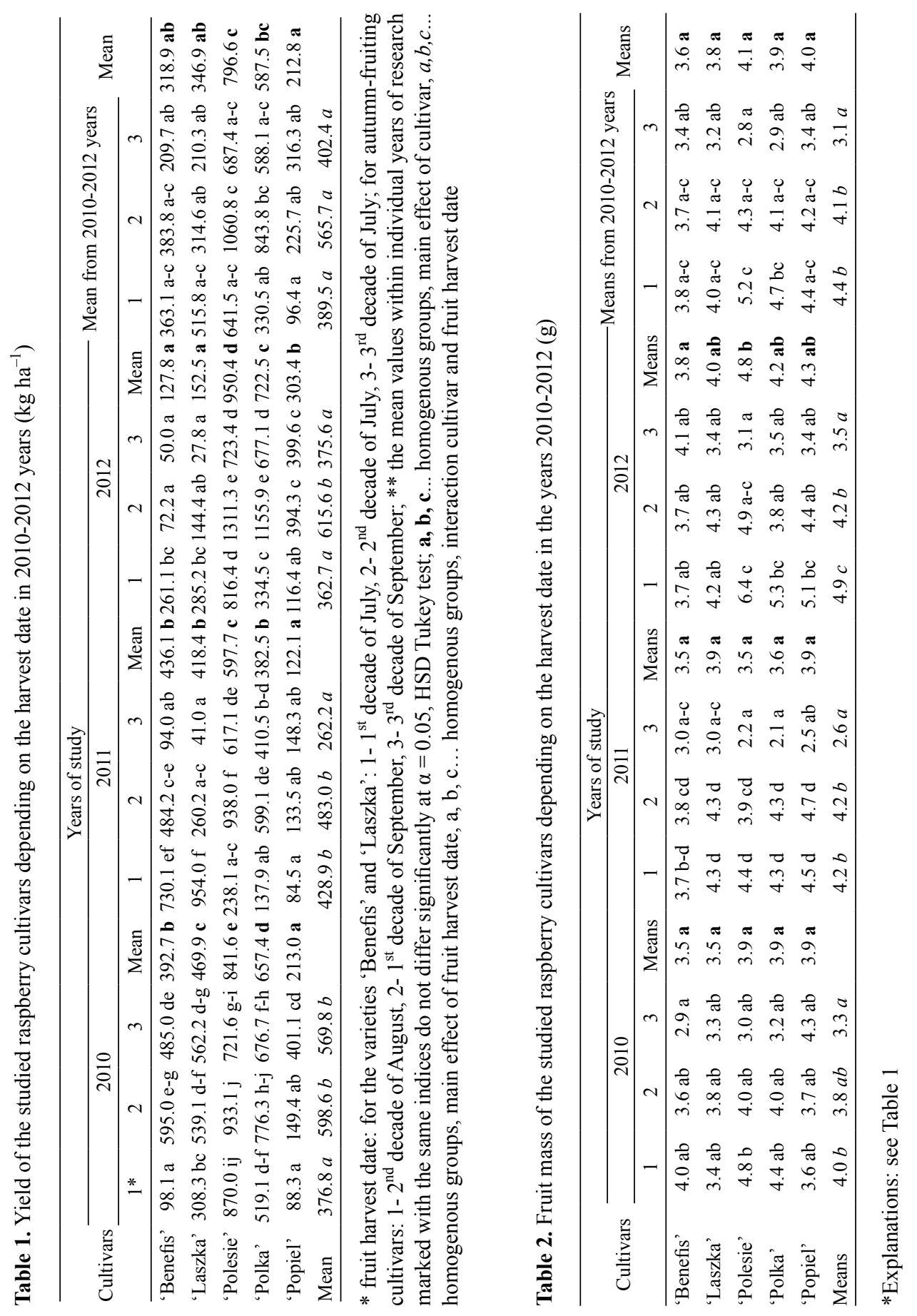




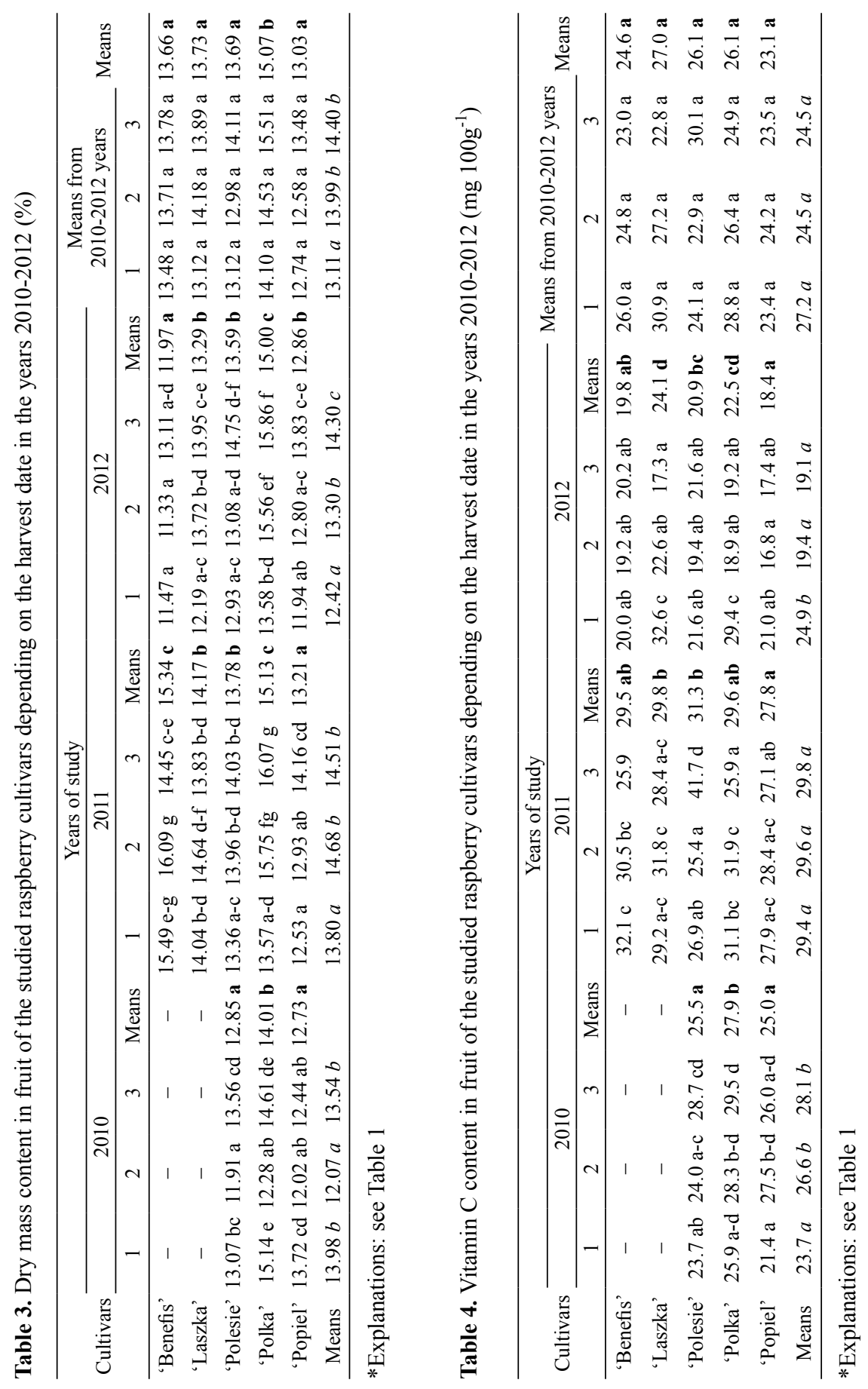



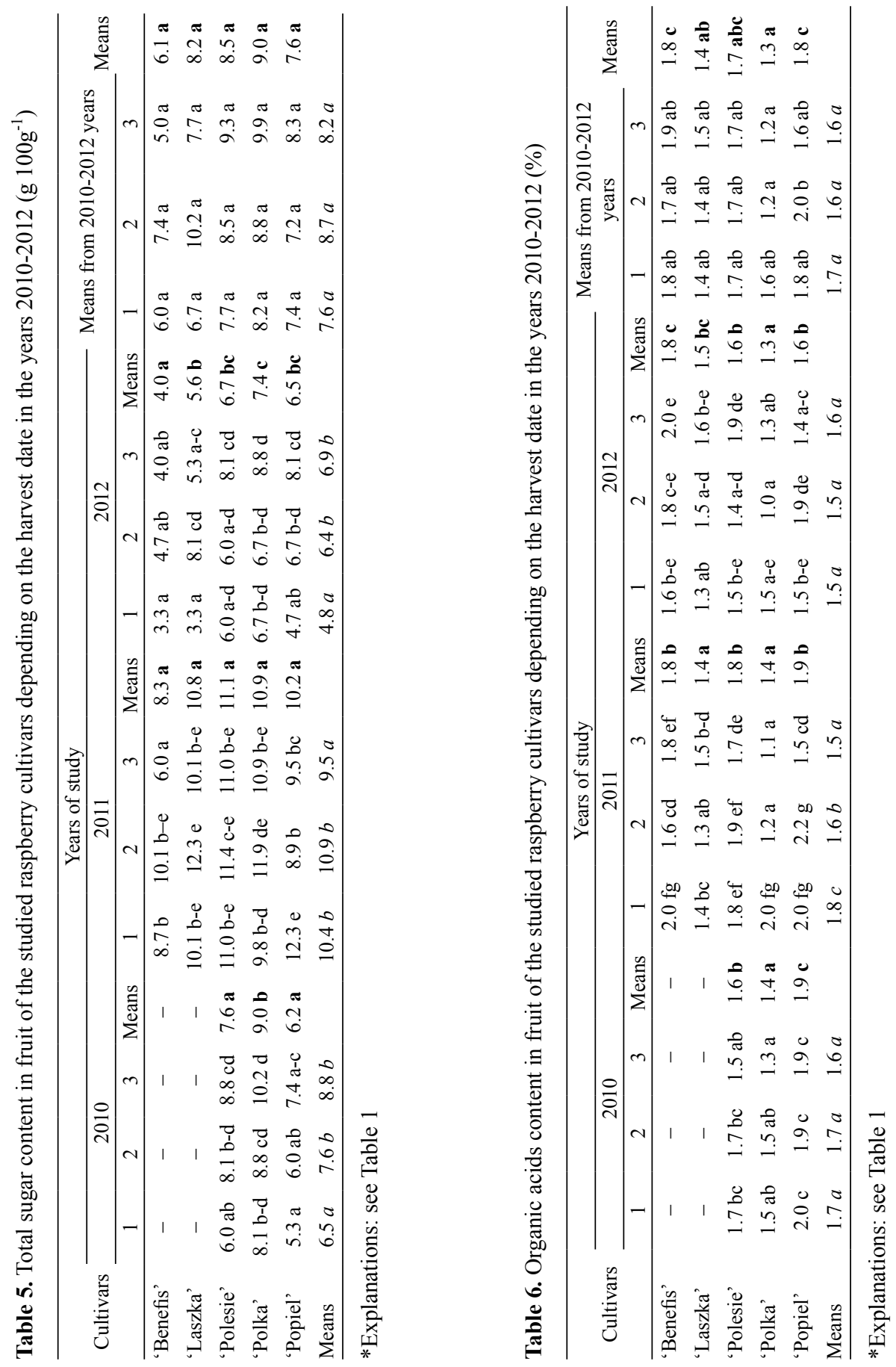
The highest content of organic acids was found in the fruit of the 'Benefis' and 'Popiel' cultivars, and the lowest in the 'Polka' cultivar (Tab. 6). The influence of the fruit harvesting time on the content of the tested component turned out to be significant only for the second year of the experiment, where the highest level was recorded in the first harvest.

\section{DISCUSSION}

The results of the study on the yields of summer- and autumn-fruiting cultivars of raspberries showed lower yields for the first or third harvesting period in individual study years, which was caused by lower levels of precipitation. The obtained results are confirmed by Laszlovszk-Zmarlicka and Smolarz (2003), Treder et al. (1993) and Krawiec and Rybczyński (2010), who found a significant effect of water shortages on the raspberry yield obtained.

The highest yields among cultivars of autumn-fruiting raspberries were reported for 'Polesie' and 'Polka' and the lowest yield for 'Popiel'. Król et al. (2008) obtained similar results in the raspberry yield estimation of these cultivars in the conditions of southern Poland. A similar relationship was noted in the case of fruit weight assessment, where 'Polesie' fruit was characterized by a higher value of this feature, however, in the current experiment no significant differences were found between the tested cultivars.

The chemical composition of raspberry fruit depends to a large extent on the agronomic factors occurring during cultivation (Grajkowski and Ochmian 2007; Rumasz-Rudnicka et al. 2009) and on the fruit maturity stage (Wang et al. 2009; Stavang et al. 2015). This confirms the results obtained with regards to the content of dry matter and sugars in the fruit, which indicate a greater accumulation of sugars in fruit collected during the second and third term of evaluation. An appropriate level of sugars and acids and the proportions between these components have a significant impact on the taste and processing value of the fruit (Wieniarska et al. 2005). The contents of sugars, vitamin C and organic acids in the raspberry fruit of the studied cultivars changed during the harvest periods and varied between particular years of the study. These differences, as shown by the studies of other authors, may be determined by genotypic traits and are subject to seasonal changes (Król et al. 2008, Mazur et al. 2014) and they may also depend on cultivation conditions (Palonen et al. 2017). 


\section{CONCLUSIONS}

1. The cultivars of 'Polesie' and 'Polka' raspberries were characterized by the highest yields among autumn-fruiting cultivars, which is why they can be propagated for cultivation in north-eastern Poland.

2. The 'Polka' fruit contained the highest amount of dry matter, while the 'Benefis' and 'Popiel' cultivars contained the highest level of organic acids.

3. The raspberry harvest in the first and second term was characterized by a higher weight of fruit, while in the second and third term, the harvest had a higher content of dry matter.

\section{REFERENCES}

Buskiene L., Uselis N., 2008. The influence of nitrogen and potassium fertilizers on the growth and yield of raspberries cv. 'Polana'. Agronomy Res., 6(1), 27-35.

Danek J., Król K., 2005. Recent situation in raspberry production in Poland. IX Rubus-Ribes Symposium Chile. Acta Hort., 777, 289-292, https://doi.org/10.17660/ActaHortic.2008.777.43

Grajkowski J., Ochmian I., 2007. Influence of three biostimulants on yielding and fruit quality of three primocane raspberry cultivars. Acta Sci. Pol., Hortorum Cultus, 6(2), 29-36.

Koszański Z., Rumasz-Rudnicka E., 2008. Effects of irrigation of berry plants (in Polish). Acta Agroph., 11(2), 437-442.

Kowalczuk J., Zarajczyk J., Leszczyński N., 2008. Evaluation of the raspberries harvest quality of the Weremczuk's firm "Natalia” combine. Inżynieria Rolnicza, 2(100), 89-93.

Krauze-Baranowska M., Majdan M., 2009. Raspberries - a source of therapeutically valuable secondary metabolites and vitamins (in Polish). Panacea, 1(26), 14-15.

Krawiec P., Rybczyński R., 2010. Fertigation efficiency of primocane-fruiting raspberry cultivars. Acta Agroph., 16(2), 347-358.

Król K., Orzeł A., Jagła J., 2008. Evaluation of twenty raspberry and blackberry cultivars grown in the south of Poland (in Polish). Zeszyty Naukowe Instytutu Sadownictwa i Kwiaciarstwa, 16, $125-134$.

Laszlovszky-Zmarlicka A., Smolarz K., 2003. The effect of nitrogen fertilization on the yielding of everbearing raspberry 'Polana'. Zeszyty Naukowe Instytutu Sadownictwa i Kwiaciarstwa, 11, 23-27.

Liu M., Li X.Q., Weber C., Lee C.Y., Brown J., Liu R.H., 2002. Antioxidant and antiproliferative activities of raspberries. J. Agric. Food Chem., 50(10), 2926-2930, https://doi.org/10.1021/ jf0111209

Mazur S.P., Nes A., Wold A.B., Remberg S.F., Aaby K., 2014. Quality and chemical composition of ten raspberry (Rubus idaeus L.) genotypes during three harvest seasons. Food Chem., 160, 233240, https://doi.org/10.1016/j.foodchem.2014.02.174

Miret J.A., Munne-Bosch A., 2016. Abscisic acid and pyrabactin improve vitamin C contents in raspberries. Food Chem., 203, 216-223, https://doi.org/10.1016/j.foodchem.2016.02.046

Palonen P., Pinomaa A., Tommila T., 2017. The influence of high tunnel on yield and berry quality in three floricane raspberry cultivars. Sci Hort., 214, 180-186, https://doi.org/10.1016/j. scienta.2016.11.049 
PN-90/A-75101/03, 1990. Fruit and vegetable products. Determination of dry matter content by gravimetric method.

PN-90/A-75101/04, 1990.Fruit and vegetable products. Determine the content of total acidity.

PN-90/A-75101/07, 1990. Fruit and vegetable products. Determine the content of total sugars and nonsugar extract.

Rumasz-Rudnicka E., Koszański Z., Kowalewska R., 2009. Influence of drip irrigation and nitrogen fertilizer on chemical composition of fruits and leaves of raspberries. Acta Agroph., 13(3), 771-779.

Stavang J.A., Freitag S., Foito A., Verrall S., Heide O.M., Stewart D., Sonsteby A., 2015. Raspberry fruit quality changes during ripening and storage as assessed by colour, sensory evaluation and chemical analyses. Sci Hort., 195: 216-225, https://doi.org/10.1016/j.scienta.2015.08.045

Treder W., Chlebowska D., Hotownicki R., 1993. Effect of irrigation and mulching with black foil on yielding of raspberry cv. 'Canby'. ActaHortic., 352, 17, https://doi.org/10.17660/ ActaHortic.1993.352.17

Wang A.Y., Chen C.-T., Wang C.Y., 2009. The influence of light and maturity on fruit quality and flavonoid content of red raspberries. Food Chem., 112, 676-684, https://doi.org/10.1016/j. foodchem.2008.06.032

Wieniarska J., Szember E., Żmuda E., Murawska D., 2005. Comparison of chemical composition of fruit in chosen raspberries cultivars Rubus idaeus L. Annales Univeritatis Mariae CurieSkłodowska Lublin-Polonia, Sectio EEE, XV, 29-33. 